Jadwiga Waniakowa

Instytut Języka Polskiego PAN, Kraków

jwaniakowa@w.krakow.pl

\title{
WPLYW ODMIANY KOŚCIELNEJ JĘZYKA NA POLSZCZYZNĘ OGÓLNĄ NA PRZYKŁADZIE UBOGACAĆ (SIĘ) - UBOGACIĆ (SIĘ)
}

Słowa klucze: odmiana kościelna języka, słownictwo, znaczenie metaforyczne, frekwencja, ironia Keywords: ecclesiastical language, vocabulary, metaphorical meaning, frequency, irony

Na początek kwestie terminologiczne. Po pierwsze, „odmiana kościelna języka” bywa najczęściej nazywana językiem religijnym (por. liczne prace Ireny Bajerowej, zwłaszcza 1988, Marzeny Makuchowskiej 1999, Iwony Pałuckiej 2000 i wielu innych autorów). Język religijny zaś - z uwagi na szeroki zakres i skomplikowanie wewnętrzne tej odmiany języka (temu zagadnieniu poświęcona jest wyjątkowo obszerna literatura, lecz nie miejsce tu, by ją przytaczać) - definiuje się zwykle przez określenie sytuacji, w jakich się go używa, oraz kręgu użytkowników (por. np. Pałucka 2000). Wymieniane w definicjach sytuacje obejmują element sacrum, a ponieważ niniejszy tekst w zamierzeniu nie odnosi się do tej sfery, preferowany jest w nim termin odmiana kościelna języka jako 'odmiana języka polskiego używana w Kościele - wspólnocie wiernych' (jest to najogólniejsza definicja zakresowa).

Stosuję termin odmiana kościelna języka (a nie, jak można by oczekiwać, język kościelny) jako bardziej oddający istotę zjawiska - zgodnie z ujęciem Karola Dejny wyrażonym w artykule Ile mamy języków polskich? (Dejna 1980), jest to bowiem odmiana języka polskiego, a nie osobny język. 
Kościelna odmiana języka jest od lat tematem niezmiernie inspirującym, toteż doczekała się olbrzymiej literatury; jest analizowana wieloaspektowo - od strony językoznawczej, socjologicznej, teologicznej itd., por. na przykład niedawną obszerną pracę Katarzyny Skowronek: Między sacrum a profanum. Studium językoznawcze listów pasterskich Konferencji Episkopatu Polski (1945-2005) (2006).

W niniejszym artykule skupiam się głównie na języku kazań i publicystyki religijnej, które siłą rzeczy oddziałują na szerokie kręgi społeczeństwa polskiego, w znakomitej większości katolickiego. Nie dokonuję tutaj jednak, pragnę to dobitnie podkreślić, charakterystyki kościelnej odmiany języka, bo było to już przedmiotem wielu dogłębnych analiz, koncentruję się jedynie na zjawiskach negatywnych, bowiem ten wariant języka - jak każda inna odmiana polszczyzny - nie jest pozbawiony usterek i błędów językowych. Wielu zresztą badaczy już od dawna zwracało na to uwagę (por. artykuły Ireny Bajerowej, np. 1988, Bożeny Matuszczyk 2003 i innych). Moim celem jest przede wszystkim analiza zjawiska przenikania elementów kościelnej odmiany języka do polszczyzny ogólnej.

Oto najczęściej wymieniane przez autorów wady kościelnej odmiany języka: nadużywanie religijnej frazeologii, błędy gramatyczne (np. wysłuchaj nasze modlitwy zamiast wysłuchaj naszych modlitw) i stylistyczne, takie jak nadużywanie stylu wysokiego (dawać świadectwo), nadużywanie przenośni (pochylać się), używanie leksemów w innych znaczeniach niż jest to przyjęte we współczesnej polszczyźnie ogólnej (np. przepowiadać 'wygłaszać kazanie'1), używanie archaizmów (ubogacać, nawiedzać), używanie swoistego „kodu religijnego”, nazywanego przez niektórych badaczy nawet „żargonem teologicznym” (Matuszczyk 2003: 55) czy „pobożnym żargonem religijnej mowy" (Chaim 1994: 121).

Jak wspomniałam, kościelna odmiana języka trafia do szerokich warstw społeczeństwa, a jej wady są bądź bezkrytycznie i w dobrej wierze kopiowane w tekstach niezwiązanych z Kościołem, bądź zauważane, wyśmiewane i parodiowane. W tym kontekście używa się nawet określenia „nowomowa kościelna”:

Nowomowa katolicka - to bardzo wdzięczny temat. Dziwię się więc, że nic na ten temat w Internecie nie znalazłem [...]. A sprawa jest przecież widoczna na pierwszy rzut oka: biskupi i księża nie mówią tak, jak normalni ludzie. Oni mają swój język, który co prawda styka się ze standardem języka polskiego, ale zarazem od tego standardu znacznie odbiega, i leksykalnie, i gramatycznie. Księża to nie „księża”, ani nawet „duchowni”, ale kapłani. Papież to nikt inny, a Ojciec Święty. Nikt nie „wykazuje zainteresowania”

1 Tu należy odnotować, że stpol. przepowiadać (przepowiedać) występowało zarówno w znaczeniu dzisiejszym 'obwieszczać przyszłe wypadki, prorokować', jak i 'mówić, głosić, podawać do wiadomości, nauczać' (por. SStp s.v.). Analogiczne znaczenia tego czasownika podaje SPXVI: 1) 'mówić, wypowiadać się ustnie lub na piśmie' w szczególności: 'nauczać wiary chrześcijańskiej, głosić słowo boże, wygłaszać kazania', 2) 'zapowiadać, mówić o tym, co się stanie w przyszłości, prorokować' (por. SPXVI s.v.). 
jakimś tematem - on pochyla się z troską. Ludzie nie „robią”, ludzie czynia, nie „kochają”, oni miłuja - i nie „chodzą”, ale kroczą, albo nawet podążaja, i co więcej zwykle nie „do”, a ku. Do wyrażenia emfazy służy zaiste, może przez podobieństwo do innego popularnego wyrazu - wiekuiste. Karierę robi zaprawdę. „Młody mężczyzna” w tym języku to zaś młodzieniec albo nawet młodzian. A zwróciliście uwagę na to, jak wciąż coś nas „ubogaca”? Kto tak mówi - „ubogacać”? Albo zamiast „odwiedziłem cmentarz” - „nawiedziłem groby”? Nawiedziłem. Ja, służebnica Pańska.

(tylemwspak.blogspot.com/2011/o4/pochylic-sie-z-troska-nad-nowomowa.html; 24.11.2012) ${ }^{2}$

W dalszej części swojej wypowiedzi autor blogu dowodzi nawet, że „nowomowa katolicka" ma wszystkie wyróżnione przez Michała Głowińskiego (1990) cechy charakterystyczne nowomowy partyjnej okresu PRL.

Prozaik Józef Łoziński (ur. 1945), wychwytując doskonale cechy i (przede wszystkim) mankamenty kościelnej odmiany języka, efektownie - dla uzyskania zawoalowanego komizmu - wykorzystuje je w swojej powieści Holding i reszta albo jak zostać bogatym w biednym państwie (2006), choć - trzeba zaznaczyć - nigdy nie odwołuje się do niej wprost (przykład niżej). Zatem nadmiar stylu wysokiego, przenośnie, archaizmy itd. w Kościele mogą wywoływać niezamierzony efekt komiczny i drwiny, a wszak nie o to chodzi w komunikacji księży z wiernymi.

Ze względu na zwięzłą formułę niniejszego tekstu nie sposób zająć się usterkami kościelnej odmiany języka całościowo, wybrałam więc tylko przykłady. Zajęłam się mianowicie czasownikiem ubogacać//ubogacić - ubogacać się//ubogacić się, typowym dla tej odmiany, i jego przenikaniem do polszczyzny ogólnej.

SJPD kwalifikuje czasownik ubogacać jako dawny z następującymi znaczeniami: a) 'czynić bogatym, majętnym; bogacić, wzbogacać' (pośw. m.in. u Syrokomli i Kołłątaja); b) 'zwiększać zasób, ilość, liczbę czego, czynić co wspanialszym, wszechstronniejszym, różnorodniejszym; bogacić, wzbogacać (pośw. m.in. u Kraszewskiego i Lelewela). Trzeba dodać, że SJPD jest jedynym słownikiem współczesnej (wprawdzie nieco dawniejszej) polszczyzny, który notuje czasownik zwrotny ubogacać się - ubogacić się, także oczywiście kwalifikując go jako dawny, ze znaczeniem 'stawać się bogatym, zamożnym; bogacić się, wzbogacać się, bogacieć' (pośw. m.in. u Zabłockiego i Słowackiego).

Zobaczmy, jak przedstawiają się poświadczenia badanych wyrazów w słownikach języka polskiego. Ubogacać (i ubogacić) notuje SStp jedynie w znaczeniu 'przysporzać dostatku' (tak!) (SStp), potem wyraz ten znajdujemy w kartotece SPXVI poświadczony niezwykle obficie zarówno w znaczeniu 'pomnażać dostatek' (u bardzo wielu XVI-wiecznych autorów, w tym w słowniku Mączyńskiego), jak i w znaczeniu

2 Zachowano oryginalną pisownię i interpunkcję blogu. 
metaforycznym (głównie u Skargi, ale też u Reja, Niemojewskiego, Górnickiego i innych) ${ }^{3}$. Autorzy używają tego czasownika w obu znaczeniach. Najlepiej obrazuje to zjawisko następujący cytat $\mathrm{z}$ Piotra Skargi: „Drudzy pierwey syny ubogácą w pieniądze, niżli w boiaźn Bożą y w rzemięsło rycerskie y w cnoty potrzebne" (Piotr Skarga, Kazania na niedziele iświęta całego roku, s. 421, szp. 1, Kraków 1595). W kartotece SPXVI napotykamy także liczne poświadczenia ubogacać się w znaczeniu podstawowym 'bogacić się’ i w znaczeniu przenośnym. Warto też odnotować, że w kartotece tej poświadczona jest stosunkowo liczna rodzina słowotwórcza tego czasownika, jak ubogacon $(y)$, ubogacany, ubogacenie, ubogaciciel. Następnie czasownik ubogacać/ubogacić znajdujemy w słowniku Trotza, dalej występuje w SL, SWil, SW, SJPD, w PSWP i w WSPP. Wszystkie te słowniki notują tylko znaczenie podstawowe 'pomnażać dostatek'. Postać zwrotną ubogacać się podaje, jak wspomniałam wyżej, jedynie Doroszewski.

Spójrzmy, jakie jest współczesne „duchowe” znaczenie ubogacaćl/ubogacić. Według PSWP ubogacić to 'uczynić kogoś, coś bogatszym duchowo, w pełni ukształtowanym'. WSPP definiuje ubogacać jako 'wzbogacać, ale nie materialnie, lecz duchowo, estetycznie itp.' i podaje następujące cytaty: Ubogacać swoją osobowość. Ubogacani Słowem Bożym udajemy się do swoich domów. Hasło opatrzone jest uwagą, że wyraz jest używany głównie w tekstach religijnych.

Jak wspomniałam wyżej, kartoteka SPXVI dostarcza wielu przykładów, że w XVI w. zaczęto używać czasowników ubogacać (się) / ubogacić (się) zarówno w znaczeniu prymarnym 'pomnażać dostatek', jak i „duchowym”. To ostatnie znaczenie używane było jednak wtedy i później najczęściej w kontekście religijnym i późniejsze słowniki go nie notują (por. wyżej). Warto przy tym zaznaczyć, że czasowniki ubogacać/ubogacić występują w niektórych dawnych tłumaczeniach Biblii. Kluczowy jest tu fragment drugiego listu św. Pawła do Koryntian (II Kor 8, 9), w zależności od tłumaczenia, zawierający ów czasownik bądź nie zawierający go. Oto stosowne przykłady.

- Biblia Leopolity (1561):

Albowiem wiećie łáskę Páná nássego Jezu Chrysthá, że sie sthał ubogim dla was, będąc bogatym, ábyśćie iego ubostwem stáli sie bogátemi (II Kor 8, 9).

- Biblia brzeska (protestancka) (1563):

Albowiem wiecie dobrotliwość Pana naszego, Jezu Krysta, iż się dla nas ubogim stał, będąc bogaty, abyście ubogaceni byli ubóstwem jego (II Kor 8, 9).

- Biblia w tłumaczeniu ks. Jakuba Wujka (1599):

Albowiem znacie łaskę Pana naszego Jezusa Chrystusa, że dla was stał się ubogim, będąc bogatym: abyście wy zbogacieli (II Kor 8, 9).

3 Za czasochłonne odszukanie i przysłanie mi wszystkich materiałów dotyczących ubogacać (się) // ubogacić (się) z kartoteki SPXVI dziękuję ogromnie w tym miejscu Pani Magister Małgorzacie Pierzgalskiej z Torunia. 
W czasach współczesnych interesujący nas czasownik pojawił się w tłumaczeniu Biblii dokonanym przez ks. bpa Kazimierza Romaniuka w drugim wydaniu Biblii Tysiąclecia (1971) i w Biblii warszawsko-praskiej ${ }^{4}$ (1976):

Znacie przecież łaskę Pana naszego Jezusa Chrystusa, który będąc bogaty, dla was stał się ubogim, aby was ubóstwem swoim ubogacić (II Kor 8, 9).

Można założyć, że tłumacz, profesor nauk biblijnych, znał doskonale tekst Biblii Brzeskiej (por. wyżej).

Wydaje się, że II wydanie Biblii Tysiąclecia stanowi początek współczesnej kariery czasownika ubogacać w znaczeniu „duchowym”. Musiało jednak minąć trochę czasu, zanim odnowiony, choć znany od staropolszczyzny wyraz w odkrytym na nowo znaczeniu utorował sobie drogę wśród polskiej społeczności katolickiej. Stopniowo był jednak coraz częściej używany w odmianie kościelnej języka. Zdzisław Pietrasik twierdzi, że:

Prymasowi Glempowi zawdzięczamy czasownik ubogacać, którym dziś chętnie posługują się zwykli księża, a nawet niektórzy znani z nieprzeciętnego patriotyzmu politycy. Ostatnio ubogacaniem zajął się prof. Miodek, proponując rozsądne rozróżnienie: bogacenie się - w sferze materialnej, ubogacanie - w sferze duchowej. Może się przyjmie („Polityka”, 16 lipca 2005).

Można zatem założyć, że prymas Glemp ten czasownik w znaczeniu „duchowym” spopularyzował. Warto też przytoczyć szerzej opinię Jana Miodka, który uznając czasownik ubogacać za całkowicie poprawny od strony formalnej, zauważa, że budzi on jednak „poprawnościowe niepokoje” i ,jest przedmiotem zgryźliwych uwag”. Miodek próbuje zatem dociec przyczyn tej sytuacji:

Po pierwsze - za naturalniejszą długo jeszcze będzie uchodzić forma wzbogacić - też wywiedziona od podstawy bogaty, tyle że ukształtowana za pomocą formantów $w z$ - oraz -ić. Po drugie - jak informują słowniki, czasownikowy twór ubogacić funkcjonuje przede wszystkim w kręgach duchowieństwa i powinien być używany w znaczeniu 'uczynić bogatszym wewnętrznie, duchowo, powiększyć zasób duchowy, niematerialny': „ubogacić duszę przeżyciami religijnymi, ubogacić darami Ducha Świętego, ubogacić łaską Bożą". Jeśli zatem osoba duchowna mówi też np. o ubogaceniu kościoła nowymi witrażami czy dzwonami, to taka konstrukcja grzeszy już pewną manierycznością, sztucznością. Oczekiwalibyśmy w niej tradycyjnego wzbogacenia się o nowe witraże, o dzwony (albo nowymi witrażami, dzwonami). Tymczasem księża zaczynają coraz częściej poszerzać zakres użycia owego ubogacania się o sferę materialną, a to drażni.

W dalszej części tekstu autor zajmuje się rozprzestrzenieniem omawianego czasownika w innych sferach życia:

4 Jest to również przekład Biblii autorstwa ks. bpa Kazimierza Romaniuka. W roku 1976 ukazał się drukiem Nowy Testament, zaś w roku 1997 całość Biblii. 
[...] ubogacanie spotkać można w tekstach - wydawałoby się - najodleglejszych stylistycznie od kręgów kościelnych. Oto np. w jednym z czasopism poświęconych motoryzacji ukazał się niedawno mój artykuł na temat języka tego obszaru cywilizacyjnego. Proszę sobie wyobrazić, że redakcja poprzedziła go własnym podtytułem: „Jak motoryzacja ubogaca polszczyznę". Doczekaliśmy się zatem ubogacania polszczyzny!!! Jest to zarazem przykład, w odniesieniu do którego można mówić o wpływie języka kościelnego na polszczyznę ogólną.

(http://wiadomosci.onet.pl/kiosk/religia/jak-kosciol-sie-wzbogaca-nowymisrodkami-stylistyc,1,3350021,wiadomosc.html; 24.11.2012).

Rzeczywiście znaczenie „duchowe” czasownika ubogacać, zwłaszcza w odmianie kościelnej języka, przyjęło się i nie budzi kontrowersji. Jednak wyraz ten zaczął się upowszechniać i w przenośnym znaczeniu jest używany także w polszczyźnie ogólnej (w kontekstach neutralnych lub ironicznych). Frekwencja jego stopniowo wzrasta. Oto przykłady występowania wyrazu ubogacać wzięte z NKJP:

A ubogacać się można jedynie przez ciągły przepływ towarów z jednej firmy do drugiej, z jednej kieszeni do trzeciej (J. Łoziński, Holding i reszta, 2006).

Celowe zastosowanie przez autora powieści czasownika w znaczeniu dawnym (XVI w., por. wyżej), ale w kontekście współczesnym potęguje ironię w obliczu dzisiejszego metaforycznego używania go w odmianie kościelnej języka.

W Wielkiej Brytanii osoby z zespołem Downa mogą czuć się pełnoprawnymi członkami społeczeństwa bez niczyjej łaski. Nie muszą nikogo „ubogacać" ani też robić spektakularnych postępów (A. Sobolewska, Cela. Odpowiedź na zespół Downa, 2009).

Cudzysłów pokazuje świadomość autorki książki (rodzaju poradnika psychologicznego), że przejęła wyraz z innej odmiany języka. Nadto widać także ironię wynikającą $\mathrm{z}$ kontekstu.

Chcemy żyć sprawami Europy, stanowić jej integralną część, czerpać z jej bogactw i ubogacać przyszłymi dokonaniami (E. Michalak, Expressem do integracji, „Gazeta Poznańska", 8.04.2003).

Mamy tu do czynienia $\mathrm{z}$ nienacechowanym użyciem omawianego czasownika $\mathrm{w}$ artykule prasowym. Po przeanalizowaniu większości przykładów z NKJP przekonałam się, że użyć tego typu jest bardzo dużo. Świadczą one dobitnie o przenikaniu ubogacać (się) / ubogacić (się) do polszczyzny ogólnej. Warto dodać, że typ źródła nie ma wpływu na sposób użycia (neutralnego bądź ironicznego) czasownika. Oto frekwencja tych czasowników w NKJP, gdzie przeszukiwany zbiór zawiera 1524696745 słów:

- Ubogacać (się) - znaleziono 806 akapitów pasujących do zapytania;

- Ubogacić (się) - znaleziono 900 akapitów pasujących do zapytania. 
Gdy sprawdza się występowanie ubogacać (się) / ubogacić (się) w Google, otrzymuje się następujące wyniki: ubogacać (się): ok. 415 oo; ubogacić (się): ok. 122000 (dostęp: 10.04.2013).

Warto zobaczyć, jak przedstawia się frekwencja ubogacać (się) w rozkładzie według typu źródła (analiza za NKJP):

Wykres 1. Frekwencja czasownika ubogacać (się) w różnych źródłach

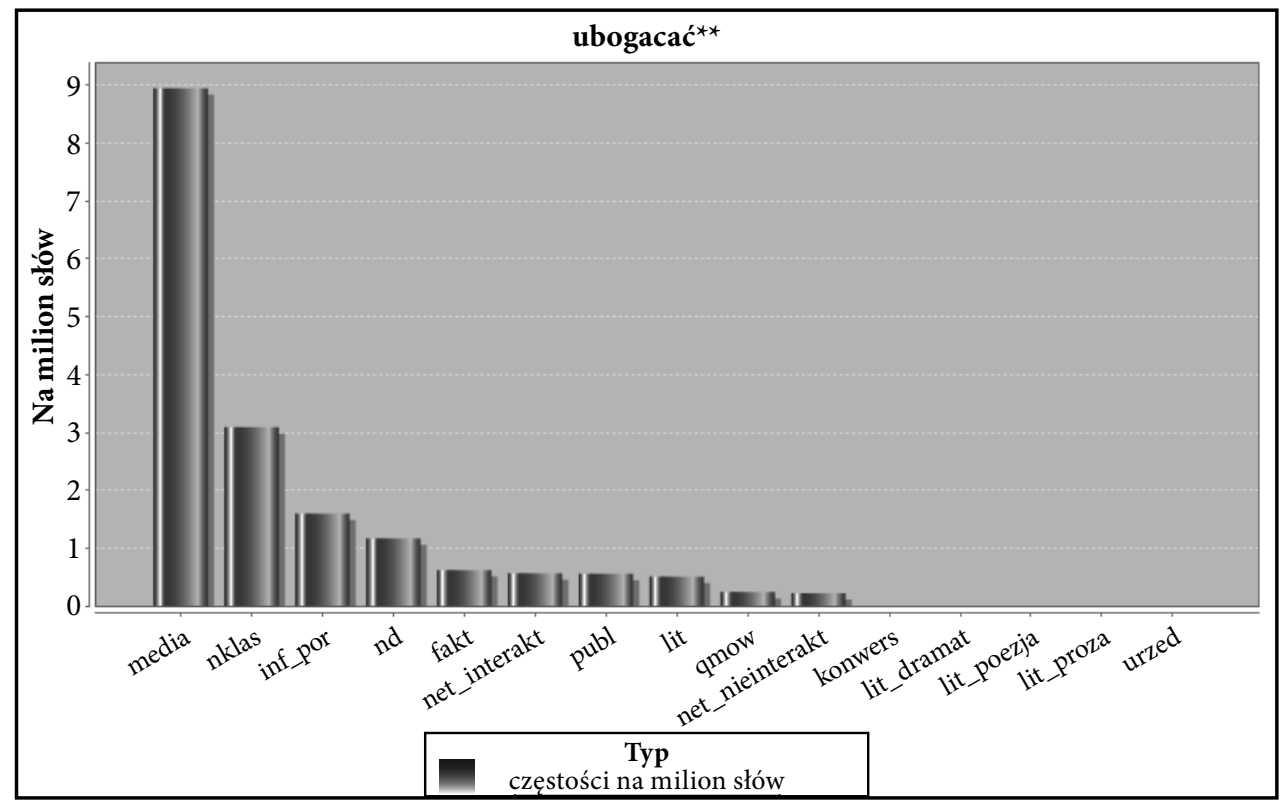

Z wykresu widać, że czasownik najczęściej jest używany tekstach mówionych w mediach, w tekstach niesklasyfikowanych („innych”), informacyjno-poradnikowych i naukowo-dydaktycznych. Ma niską frekwencję w literaturze faktu, w tekstach internetowych interaktywnych (na forach, w blogach $\mathrm{z}$ komentarzami, w listach dyskusyjnych), w tekstach publicystycznych i w literaturze pięknej. Śladowo występuje w tekstach quasi-mówionych i w nieinteraktywnych tekstach internetowych (np. na stronach domowych). W ogóle nie pojawia się zaś w tekstach mówionych konwersacyjnych, poezji i w pismach urzędowych.

Interesująca jest także analiza występowania czasownika ubogacać (się) ze względu na kanał przekazu (za NKJP, por. niżej). Okazuje się, że czasownik ten pojawia się najczęściej w języku mówionym, w miesięcznikach i książkach, obecny jest także, choć w nieco mniejszym zakresie, w tygodnikach i dziennikach oraz w Internecie. 
Wykres 2. Frekwencja czasownika ubogacać (się) ze względu na kanał przekazu

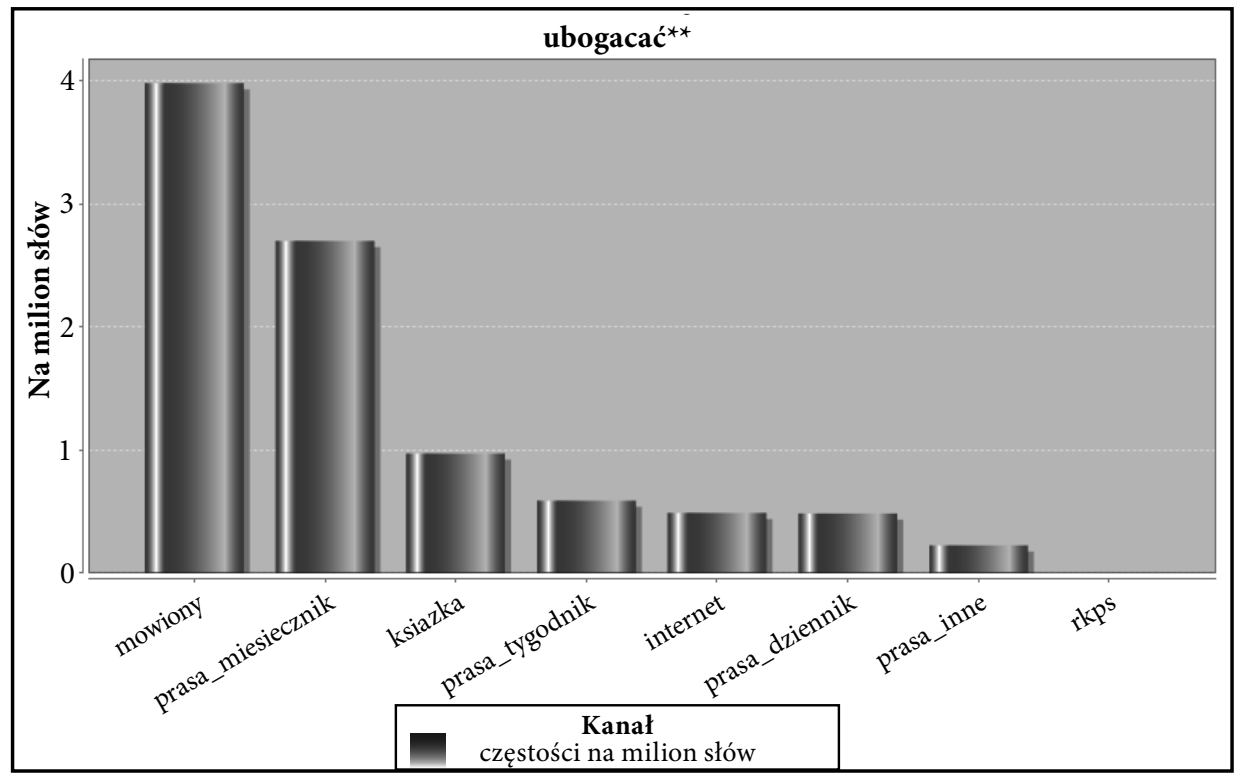

Warto też przyjrzeć się frekwencji ubogacać (się) w czasie. Wykres tego rodzaju jest również dostępny w NKJP:

Wykres 3. Rozkład w czasie frekwencji czasownika ubogacać (się)

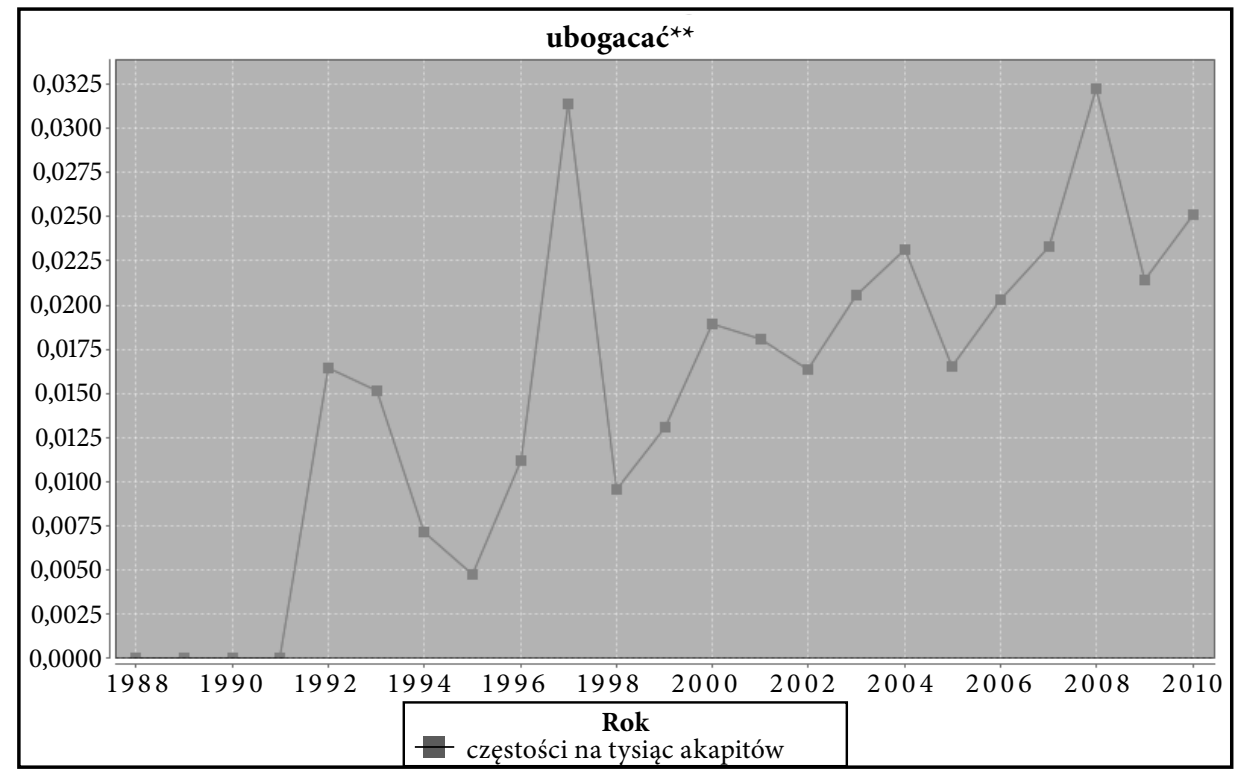


Wykres sporządzony na podstawie materiałów z NKJP pokazuje, że czasownik pojawił się w roku 1992 od razu w stosunkowo wysokiej częstości użycia i jego występowanie ma tendencję wzrostową ( $\mathrm{z}$ niewielkimi wahaniami) w czasie.

W ten sam sposób zanalizowałam także ubogacić (się), które charakteryzuje się niemalże identycznymi parametrami w zakresie frekwencji.

Trzeba mieć na uwadze, że poddałam tu analizie tylko jeden czasownik, typowy dla kościelnej odmiany języka, który dobitnie ukazuje jej wpływ na polszczyznę ogólną. Wpływ ten jest znaczny, ponieważ rozprzestrzenianie się charakterystycznego dla tej odmiany słownictwa i frazeologii trwa, por. na przykład obecnie coraz bardziej się upowszechniający w polszczyźnie ogólnej czasownik pochylać się / pochylić się w znaczeniu metaforycznym 'zajmować się kimś lub czymś z troską i uwagą' (definicja znaczenia za WSJP) ${ }^{5}$, zwrot dawać świadectwo i wiele innych. Jednakże zebranie większego materiału leksykalnego i prześledzenie jego użycia w polszczyźnie wymagałoby długotrwałych kompleksowych badań, a opis uzyskanych wyników zająłby sporo miejsca, zatem tutaj jedynie sygnalizuję to zagadnienie. Przenikanie słownictwa (a nawet całych konstrukcji) z kościelnej odmiany języka do polszczyzny ogólnej wynika ze wzrastającej popularności tej odmiany, spotykanej nie tylko w kościele (jako miejscu), ale też w mediach, i stąd traktowanej w świadomości społecznej jako wzorzec językowy. Natomiast istniejący opór przeciw przejmowaniu tych elementów jest spowodowany wyczuciem językowym (czy też świadomością językową) części społeczeństwa, która odczuwa, że styl wysoki i napuszony nie pasuje do świeckich i błahych treści.

Podsumowując niniejsze rozważania, wypada stwierdzić, że przenikanie do polszczyzny ogólnej elementów odmiany kościelnej języka nie jest zjawiskiem pożądanym, ponieważ spotyka się z drwiącą postawą części społeczeństwa, wywołuje żarty i chęć parodiowania, inna jego część zaś przejmuje bezrefleksyjnie sposób komunikacji w Kościele, narażając przez to na lekceważenie zarówno siebie, jak i całą kościelną odmianę języka.

Środkiem zaradczym w tej sytuacji byłoby większe uwrażliwienie językowe księży, to jest ściślejsze dostosowanie języka do konkretnej sytuacji, nienadużywanie stylu wysokiego, archaizmów i przenośni. Wówczas kościelna odmiana języka nie budziłaby tylu (w sumie dość negatywnych) emocji i nie służyłaby w takim stopniu, jak obecnie, jako źródło materiału językowego częstokroć nieprzystającego do zupełnie świeckiego kontekstu.

5 O czasowniku pochylać się w odmianie kościelnej języka pisze Bożena Matuszczyk (2003: 61-62). Pochylać się występuje w słownikach od staropolszczyzny, trzeba jednak podkreślić, że jego metaforyczne znaczenie, co może dziwić, figuruje jedynie w ISJP i w WSJP (por. wyżej). Charakterystyczne, że brak tego znaczenia w słownikach historycznych i dawnych. Warto przy tym podkreślić, że pochylać się / pochylić się we wspomnianym znaczeniu w znacznie większym stopniu niż ubogacać (się) / ubogacić (się) weszło do polszczyzny ogólnej. 


\section{Literatura}

BAJEROWA I., 1988, Kilka problemów stylistyczno-leksykalnych współczesnego polskiego języka religijnego, [w:] M. Karpluk, J. Sambor (red.), O języku religijnym. Zagadnienia wybrane, Lublin, s. 21-44.

Снаiм W., 1994, Kazanie jako komunikat, [w:] W. Przyczyna (red.), Fenomen kazania, Kraków, s. 98-135.

DejnA K., 1980, Ile mamy języków polskich?, „Język Polski” LX, s. 30-43.

GŁowı́́ski M., 1990, Nowomowa po polsku, Warszawa.

ISJP: M. Bańko (red.), Inny słownik języka polskiego, Warszawa 2000.

ŁozIŃsKi J., 2006, Holding i reszta albo jak zostać bogatym w biednym państwie, Warszawa.

Maкuсношsка M., 1999, Miejsce języka religijnego w typologii współczesnych odmian polszczy$z n y$, [w: Z Z. Adamek, S. Koziara (red.), Od Biblii Wujka do współczesnego języka religijnego.

Z okazji 4oo-lecia wydania Biblii ks. Jakuba Wujka, Tarnów, s. 176-189.

Matuszczyк B., 2003, O modelu komunikacji we współczesnym kaznodziejstwie, [w:] P. Urbański (red.), Retoryka na ambonie. Z problemów współczesnego kaznodziejstwa, Kraków, s. 53-63. NKJP: Narodowy Korpus Języka Polskiego, www.nkjp.pl

PAŁucka I., 2000, Czy istnieje „język religijny”, „Język Polski”, LXXX, s. 176-184.

PSWP: H. Zgółkowa (red.), Praktyczny słownik współczesnej polszczyzny, Poznań, 1994-2005. SJPD: W. Doroszewski (red.), Słownik jezzyka polskiego, Warszawa 1958-1969.

Skowroneк K., 2006, Między sacrum a profanum. Studium językoznawcze listów pasterskich Konferencji Episkopatu Polski (1945-2005), Kraków.

SL: S.B. Linde, Słownik jezzyka polskiego, Warszawa 1807-1814.

SPXVI: Słownik polszczyzny XVI wieku, pod red. M. R. Mayenowej, Wrocław, 1966-2004.

SsтP: Słownik staropolski, pod red. S. Urbańczyka, t. I-XI, Wrocław 1953-2002.

SW: J. Karłowicz, A. Kryński, W. Niedźwiedzki, Słownik języka polskiego, Warszawa 1900-1927. SWIL: A. Zdanowicz i in., Słownik języka polskiego, Wilno 1861.

Trotz A., 1764, Mownik polsko-niemiecko-francuski [...], Leipzig.

WSJP: P. Żmigrodzki (red.), Wielki słownik języka polskiego, Kraków 2007 - http://www.wsjp.pl WSPP: A. Markowski (red.), Wielki słownik poprawnej polszczyzny, Warszawa 2009.

\section{The influence of ecclesiastical language on standard Polish Summary}

The article discusses the influence of ecclesiastical language on standard Polish. It first presents the the faults of this variety, and then some examples of the ecclesiastical vocabulary. The author examines in particular one verb that is typical of contemporary ecclesiastical language, ubogacać (się) / ubogacić (się) 'to enrich (oneself)'. She analyses its historical and present day meaning, its history and the contexts in which it is used, and observes that it has spread out onto standard Polish. 